\title{
Temperature Influence on the Process of the Gelation of the Engine Oil
}

ISSN: 2637-8035

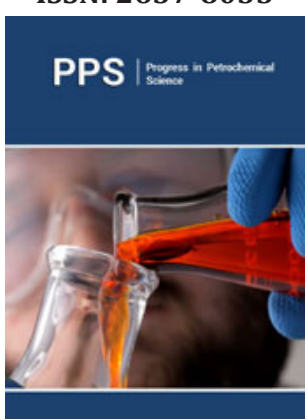

*Corresponding author: Krzysztof Biernat, Department for Fuels and Bioeconomy, Poland

Submission: 偣 July 02, 2020

Published: 僵July 29, 2020

Volume 3 - Issue 3

How to cite this article: Krzysztof Biernat, Monika Ziółkowska. Temperature Influence on the Process of the Gelation of the Engine Oil. Progress Petrochem Sci. 3(3). PPS. 000565. 2020.

DOI: $10.31031 /$ PPS.2020.03.000565

Copyright@ Krzysztof Biernat, This article is distributed under the terms of the Creative Commons Attribution 4.0 International License, which permits unrestricted use and redistribution provided that the original author and source are credited.

\author{
Krzysztof Biernat ${ }^{1 *}$ and Monika Ziółkowska² \\ ${ }^{1}$ Department for Fuels and Bioeconomy, Poland \\ ${ }^{2}$ Department of Petroleum Engineering, Poland
}

\begin{abstract}
The article discusses the process of gelation of engine oils and its influence on exploitative properties. The results of research on the propensity of engine oils for gelation at low and high temperatures are presented. The influence of various factors such as: base oil, vegetable oil, FAME and soot on the gelling process was determined. It was found that the cause of gelation of oils, depending on the operating conditions, oil components, may be several factors independent of each other. These factors are discussed in the article.
\end{abstract}

Keywords: Gel; Gelling process; Engine oil; Oil components; Vegetable oil; Fame; Soot

\section{Introduction}

In the 1990s, the problem of forming a gelatinous (gel) oil structure in the operation of vehicles powered by diesel oil appeared in Poland. However, the problem of gelation of motor oils was already noticed in Europe in the 1980s. At that time, it was assumed that this could be related to the introduction of a new category of engine oils, including the CD class according to API. The quality class CD introduced then a new generation of additives improving detergents and dispersants. In addition, the process of limiting sulfur content in diesel oil started, which was initially thought to have adversely affected the performance of engine oil. In Poland, the phenomenon of gelation was observed mainly in the late autumn and early spring periods, i.e. during periods in which large temperature fluctuations could occur. In winter or summer, when the temperature jumps were not large, this problem did not occur. In addition, the problem of gelation included engine oils of various quality and viscosity grades of known domestic and foreign producers. A characteristic feature of gelation is the rapid increase in kinematic viscosity at both $40^{\circ} \mathrm{C}$ and $100^{\circ} \mathrm{C}$, the other parameters do not change much in relation to fresh oil.

The problem of gelation is a very unfavorable phenomenon for the engine. Gelled oil completely loses its operational functions, i.e. it does not provide lubrication, does not dissipate heat, does not neutralize acidic products originating, among others from incomplete burning of fuel, etc. which leads to engine seizure. Based on the collected literature on the operational problems of motor oils, including the phenomenon of gelation, several factors can be distinguished that can cause the formation of a gelatinous oil structure. The most important of them are:
A. Soot content
B. Base oil composition
C. Content of vegetable oil or fatty acid methyl esters

But in addition to the factor that triggers the gelling process, temperature also plays a key role. Under the same atmospheric conditions, during the operation of vehicles, some oils show a greater tendency to form a gel while others are less and undoubtedly related to the 
temperature, not only of the engine itself, but also of the ambient temperature.

\section{Gel Structure}

A gel is a colloidal system that consists of at least two components. Each of the components forms a separate continuous phase extending over the entire volume of the mixture. The gelling agent forms a rigid, branched, porous network spreading in the liquid constituting the second component of the gel, causing it to immobilize [1]. The gel structure consists of network nodes, loops, and free ends of chains. The diagram of the gel structure is shown in Figure 1 [2,3]. The division of gels is related to the type of interactions responsible for creating a rigid network, and thus with the type of gelling agent. There are chemical gels in which in the process of gel formation gelling agent molecules create covalent bonds between them, and physical gels in which the molecules of the gelling agent are bound by much weaker intermolecular interactions, mainly hydrogen bonds and electrostatic, dipoledipole interactions, van der Waals, as well as hydrophobic. The physical gels are thermally reversible, because the change of external parameters such as temperature and pressure lead to the disintegration of the gel network. In contrast, chemical gels are formed in the polycondensation, polymerization and copolymerization of multifunctional monomers or because of introducing a cross-linking agent into the polymer. The chemical (covalent) bonds formed in this way create nodes of the network [4]. The best-known methods for obtaining gels are shown in Figure $2[4,5]$.

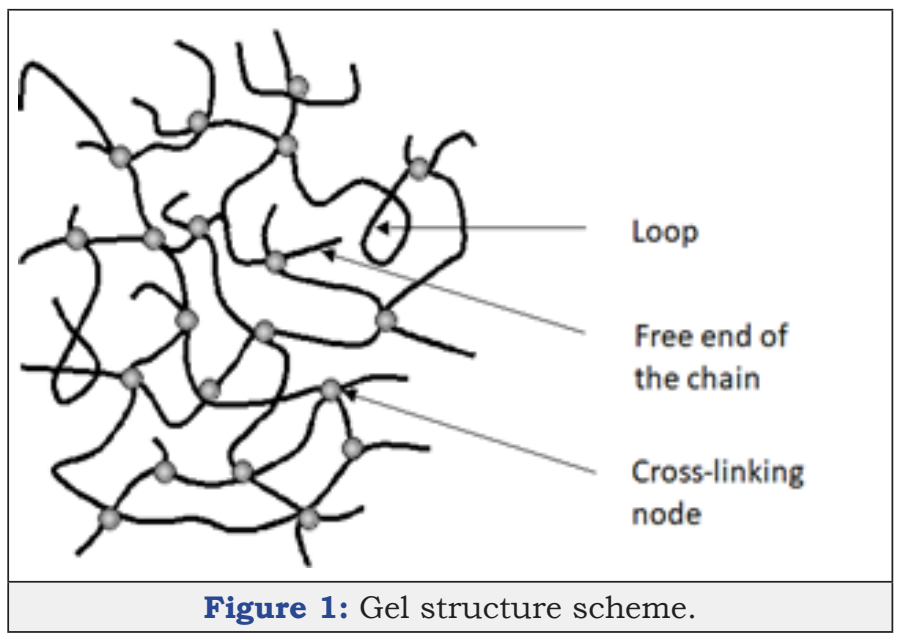

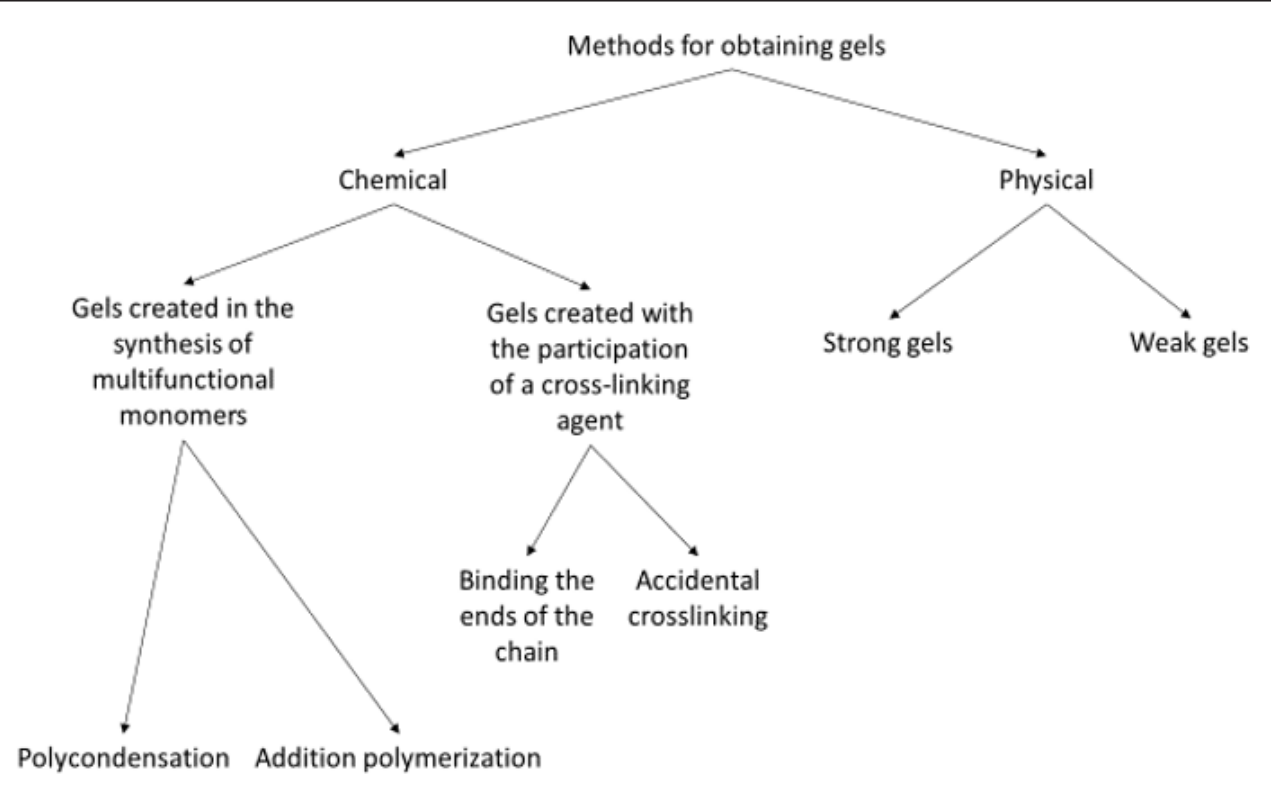

Figure 2: Chemical and physical methods of obtaining gels.

\section{Gelation Temperature and Gelation Index}

Multigrade engine oils have been introduced to reduce the viscosity of the oil at low temperatures to facilitate engine starting. With the easier start-up of the engine at low temperatures, there was a problem with the oil pumpability. This problem turned out to be much more serious because the lack of pumpability of the oil could lead to engine damage. In bench tests, it was found that at low temperatures we have two types of problems related to pumpability:

\section{A. High viscosity that limits flow}

B. Gelation of the oil subjected to long-term low temperature, which has been termed "air bonding", because the oil pump is aerated because of sucking oil from the oil sump along with the air [6].

Research on oil-air binding led to the development of a method for testing the tendency of oil to gel using a Brookfield scanning viscometer. The STB method as an international standard ASTM D 5133 allowed the study of the tendency of oil to form a gel. The method consists in heating the tested sample to $90{ }^{\circ} \mathrm{C}$, and then slowly cooling it, while continuously measuring the viscosity [7]. Based on this method, you can designate: 
a. Gelation Temperature

b. Gelation Index

The literature data show that the highest gelation and consequent air retention were found at temperatures much higher than those associated with limited flow, for the same class of SAE motor oils. Modern multi-grade motor oils require a maximum gelation index value of 12 . This is the value at which the resulting gels in the engine oil do not endanger the engine's operation. The value of the gelation index above 12 indicates that the oil is highly prone to gel formation in the entire volume and can lead to engine failure [7].

\section{Factors Influencing Oil Gelation Process at Low Temperatures}

In determining how the lubricant will behave at low temperatures and the likelihood of gelation, several factors must be considered. These include the composition of the base oil, the paraffin content, the flow temperature, and the depth of the refined base oil. All these factors will have a significant impact on gelation and lubricant properties at low temperatures.

\section{The effect of the composition and depth of the process of refining the base oil and the content of paraffins on the gelation process}

Crude oil naturally contains some amounts of paraffinic compounds, which may affect the oil's tendency to form the gel at low temperatures. The more paraffins or paraffin compounds in the base oil, the greater the tendency of the oil to gel. Most paraffins can be removed by refining but cannot be removed completely. During the dewaxing process, most paraffins are reduced or the paraffin structure is converted into a different structure with better low temperature properties. Usually, the more refined base oil, the higher the viscosity index and better low temperature properties [8]. Most of the oils produced on mineral bases tend to thicken significantly, as paraffin particles crystallize at low temperatures. This, in turn, extends the time needed to pump oil through the entire engine and requires more work of the starter and the battery. Therefore, considering the tendency to gel, the best mineral bases are API Group II and III oils. The API II base oils are oils obtained through the use of hydrogen catalytic processes, such as hydrotreating and mild hydrocracking during processing of vacuum distillates of crude oil, whereas API Group III base oils are oils obtained through the use of deep hydrocracking processes and hydro isomerization of distillates vacuum and hydro isomerization of paraffins [9]. Therefore, API base oils of Group II and III have a lower volatility and lower flow temperatures.

Summarizing the above considerations, it can be concluded that the less paraffinic compounds and/or the deeper refining of the base oil, the lower the tendency to gel the finished oil at low temperatures.

\section{Effect of flow temperature and oil solidification temperature on the gelation process}

The flow temperature and freezing point are important physicochemical parameters that affect the gelling process, especially for oil that will run at low temperatures. The solidification temperature is the temperature at which the oil will not flow under the influence of gravity. When the oil is cooled, the paraffins remaining in the oil begin to crystallize and solidify with each other, so that the liquid becomes more and more dense until it stops flowing. Therefore, for vehicles that will operate at extremely low temperatures, one should choose lubricating oil that has the lowest freezing point to avoid problems due to reduced flow at low temperatures [8]. Lubricants operating at low temperatures should, in addition to a highly refined oil base and the appropriate package of refining additives, also contain a depressant, an additive that lowers the freezing point.

\section{The tendency of engine oils to gelation at low temperatures}

A study of the propensity of engine oils for gelation at low temperatures was carried out by scanning using a Brookfield viscometer (STB) in accordance with ASTM D 5133-15. The test was carried out in the temperature range from $-5{ }^{\circ} \mathrm{C}$ to $-40{ }^{\circ} \mathrm{C}$ at a shear rate of $0.2 \mathrm{~s}-1$ [10]. The measurements were carried out for currently produced fresh engine oils and with the addition of fatty acid methyl esters (FAME):
A. LC - mineral engine oil SAE 15W/40 API SF/CD
B. LM - mineral engine oil SAE 15W/40 API SJ/CF
C. LSP - synthetic engine oil SAE 5W/40 API SN/CF

The above-mentioned engine oils and mixtures prepared with their use containing 30\% FAME were tested for the determination of gelatinization by the STB method. Based on the dynamic viscosity dependence on the temperature, the gelation index was determined, which is shown in Figure 3. In Figures 4-9, the dependence of dynamic viscosity on the temperature of engine oils is shown. Dependence of dynamic viscosity on temperature. Based on the obtained test results, it can be concluded that commercial oils have a low tendency to gelation. The gelation index ranged from 6.6 to 7.1. This indicates that the oils tested belong to weakly gelling oils. However, the addition of $30 \%$ FAME caused an increase in the gelation index in relation to oils not containing FAME. This indicates that oils containing an addition of fatty acid methyl esters show a very high tendency to gelation. Based on these studies, it can be concluded that fatty acid methyl esters are a gelling agent. At elevated temperatures, ester bonds in FAME break, thanks to which free radicals are formed, which build into the structure of the oil creating permanent bonds in the nodes of the network. Under the influence of cooling, the oil begins to thicken to form a gel structure [11]. 

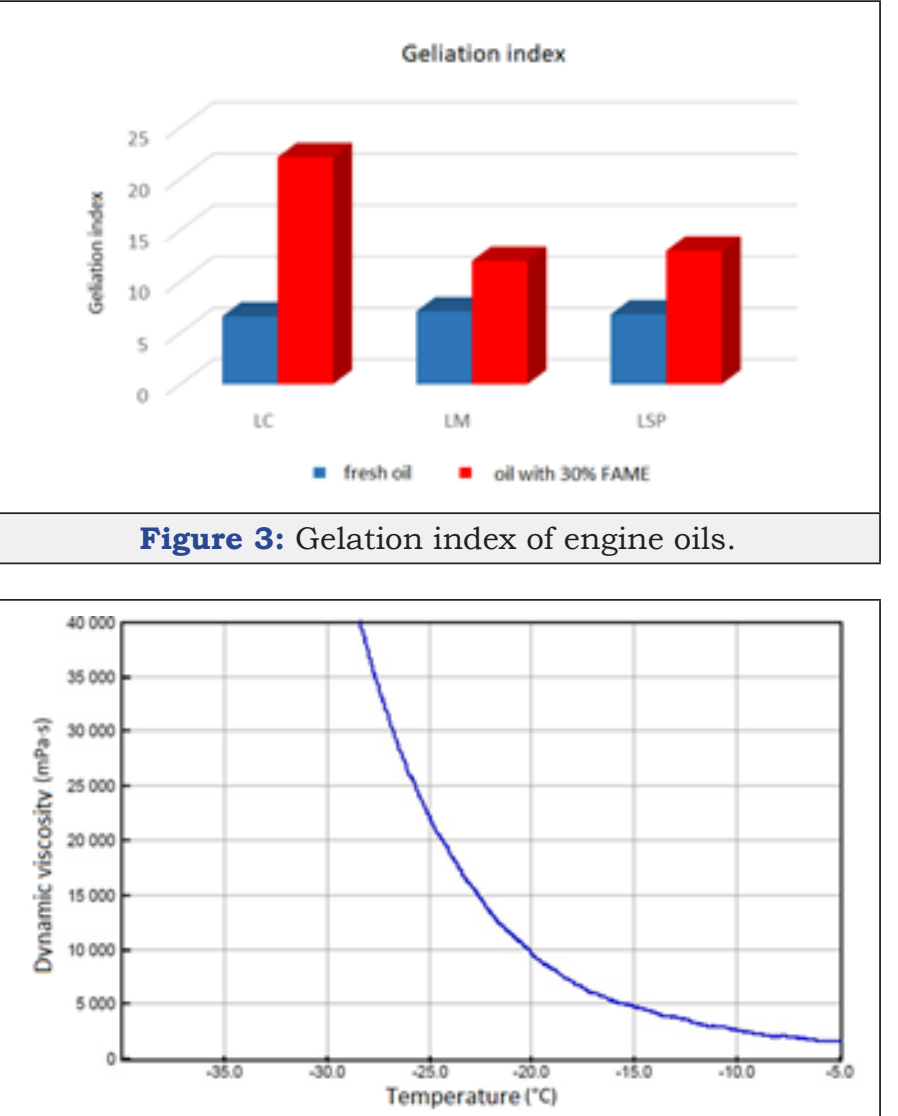

Figure 4: Fresh SAE 15W/40 API SF/CD oil.

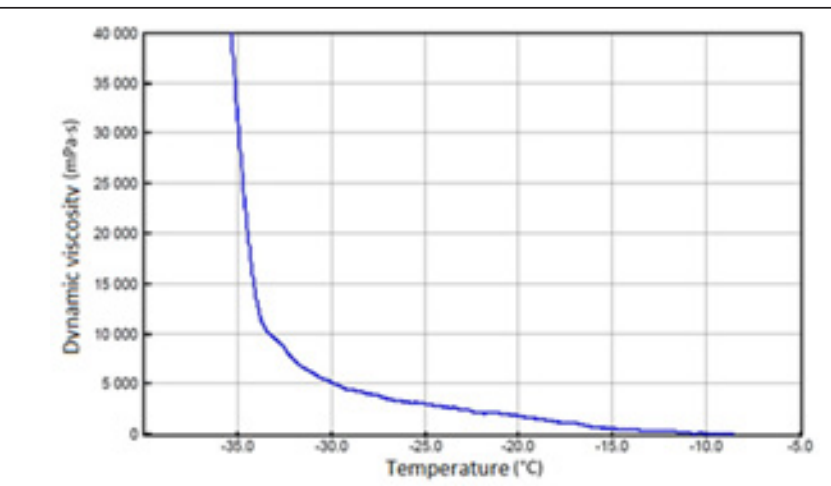

Figure 5: SAE 15W/40 API SF/CD oil with 30\% FAME.

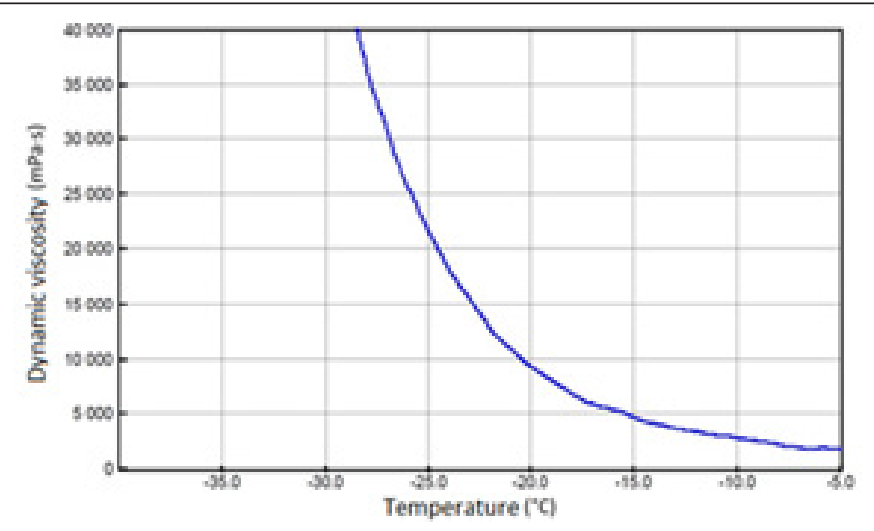

Figure 6: Fresh SAE 15W/40 API SJ/CF oil.

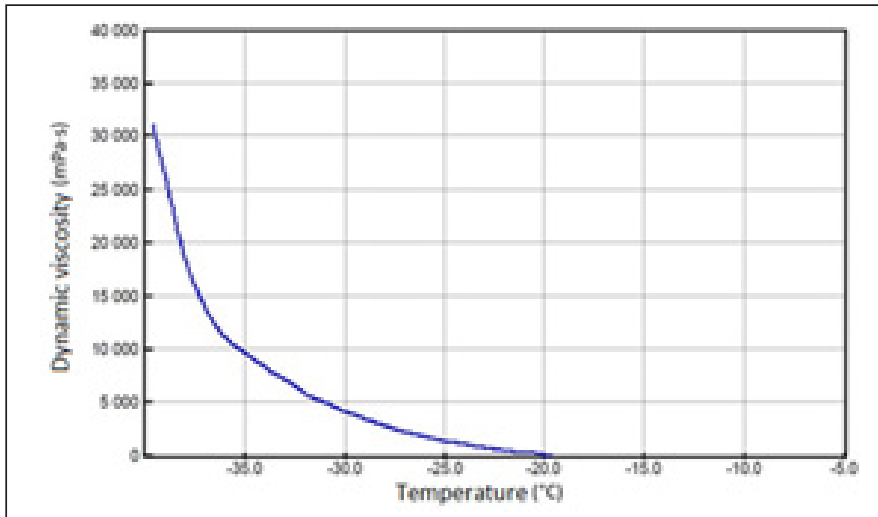

Figure 7: SAE 15W/40 API SJ/CF oil with 30\% FAME.
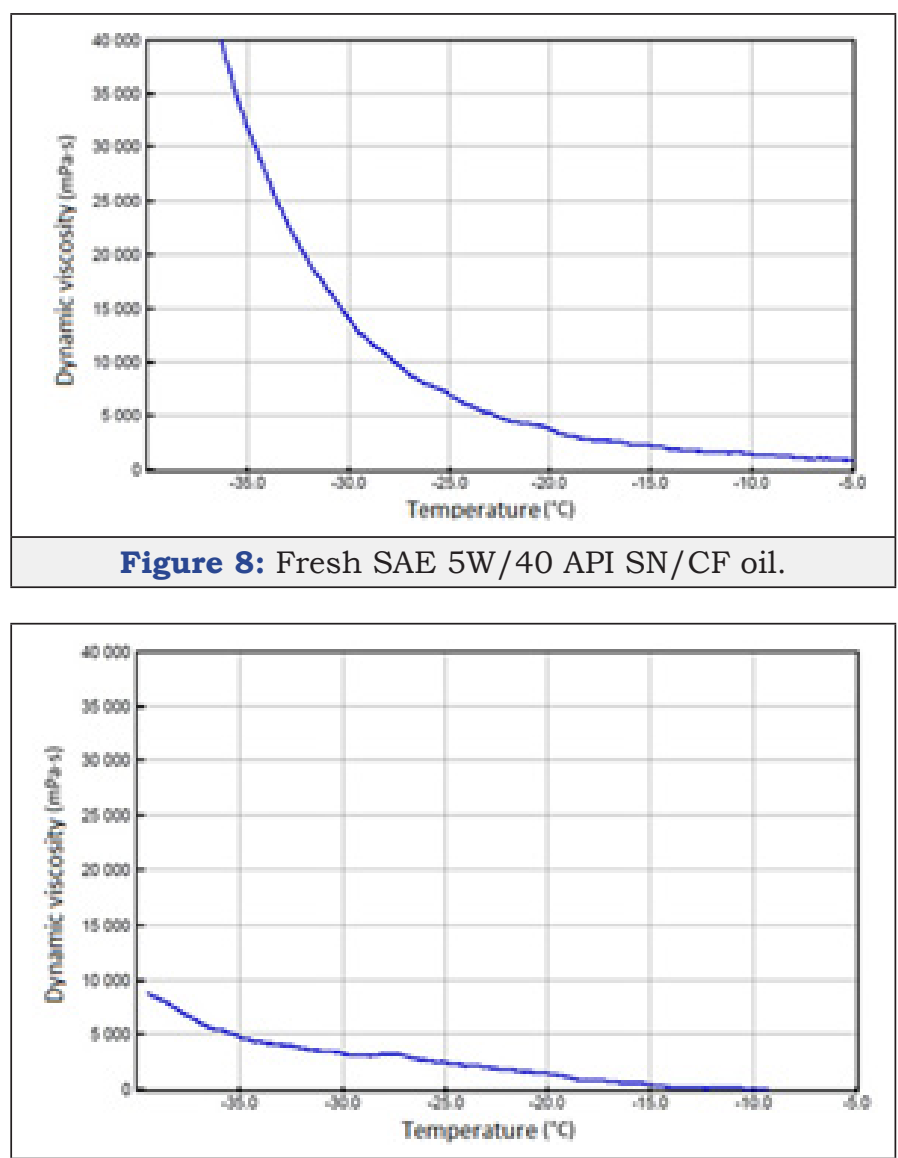

Figure 9: SAE 5W/40 API SN/CF oil with 30\% FAME.

Factors Influencing Oil Geliation Process at High Temperatures

The engine oil used on the one hand is exposed to high temperatures and products of incomplete fuel combustion that arise during operation of the engine. On the other hand, it can be diluted with fuel, which speeds up oil oxidation processes due to the content of the biocomponent in it. Additional hazards that may cause sudden, premature degradation of engine oils cause adverse interactions that may occur between oil and fuel, and usually resulting from the antagonistic effects of not always compatible components contained in both products [12]. The progressive 
oxidation leads to thickening of the oil and raising its acid number. Over time, the oil begins to become more and more saturated with soluble and insoluble oxidation products, which causes that the effectiveness of dispersing and detergent additives is insufficient to keep them suspended in oil, tar and sludge are deposited on engine components [13]. There are various toxic compounds and solid particles in the engine exhaust, the main ingredient being soot. Part of the soot does not burn and deposits on the walls of the cylinder. This soot along with the oil film is scraping through the rings and gets into the engine oil. Soot particles can also come from the destruction of oil [13].

\section{The effect of soot on the process of gelling engine oil}

The main reason for oil thickening is usually its oxidation, thermal degradation, the presence of glycol or the accumulation of soot. The tests carried out at the Institute showed that gelled oils, apart from the increase in kinematic viscosity, had the basic parameters of physicochemical properties at the level of fresh oils. The only difference was the huge amount of soot in these oils, the content of which was 17 to $25 \%$ (w/w). The soot content tests were carried out using the thermogravimetric method in the atmosphere of nitrogen and air. Thermogravimetric curves for 2 gelled oils that contain soot are presented at Figure 10. Based on thermogravimetric curves, the soot content was calculated as the difference in weight loss of the sample in mass $\%$ after its decomposition under nitrogen and air [14].

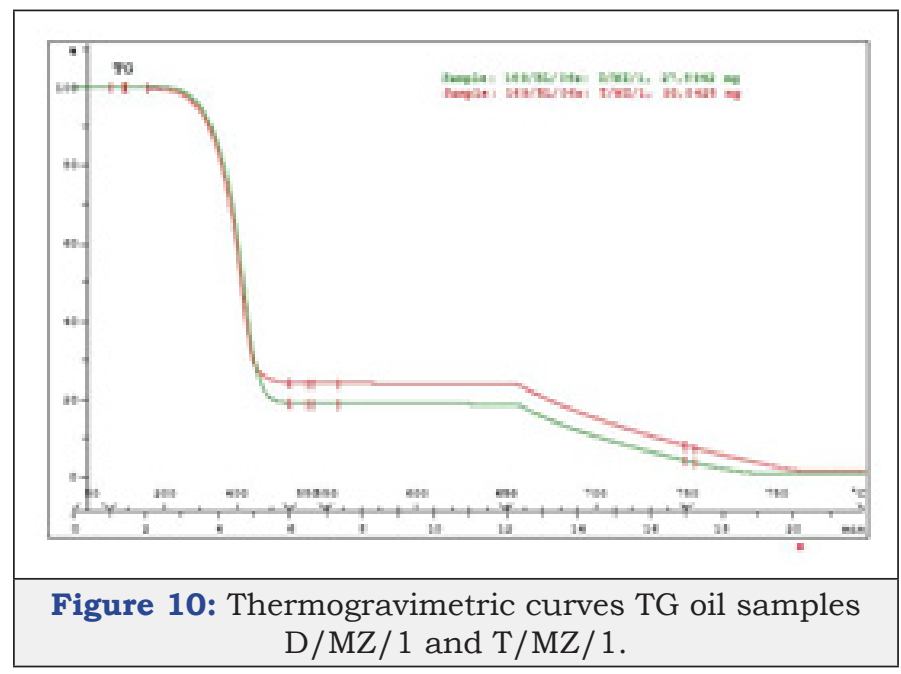

In samples marked:

a. D/MZ/1 (SAE 15W40 API CG-4), 17.6\% (w/w) was found

b. T/MZ /1 (SAE 10W40 API CF) 22.2\% (w/w) was found

For the oil sample D/MZ/1, a photo was taken under an electron microscope to determine whether the soot formed agglomerates in the entire oil volume. The black spherical spots shown in Figure 11 show that the soot in the oil accumulated in the form of agglomerates. However, Figure 12 shows fresh oil that does not contain soot. It was observed that the gelling problem occurs when the engines are fed with low soot and PAH fuels. Soot gets partially into the engine oil from the exhaust gases in which it is dispersed. Dispersed small particles of soot do not affect the increase in the kinematic viscosity of the engine oil. However, soot particles tend to agglomerate, resulting in soot aggregates that lead to a rapid increase in viscosity and even gel. A characteristic feature of the gel resulting from agglomeration of soot in engine oil is a significant increase in viscosity of the oil at temperatures of $40^{\circ} \mathrm{C}$ and $100{ }^{\circ} \mathrm{C}$. Figure 13 shows gelled engine oil containing high amounts of soot [14].
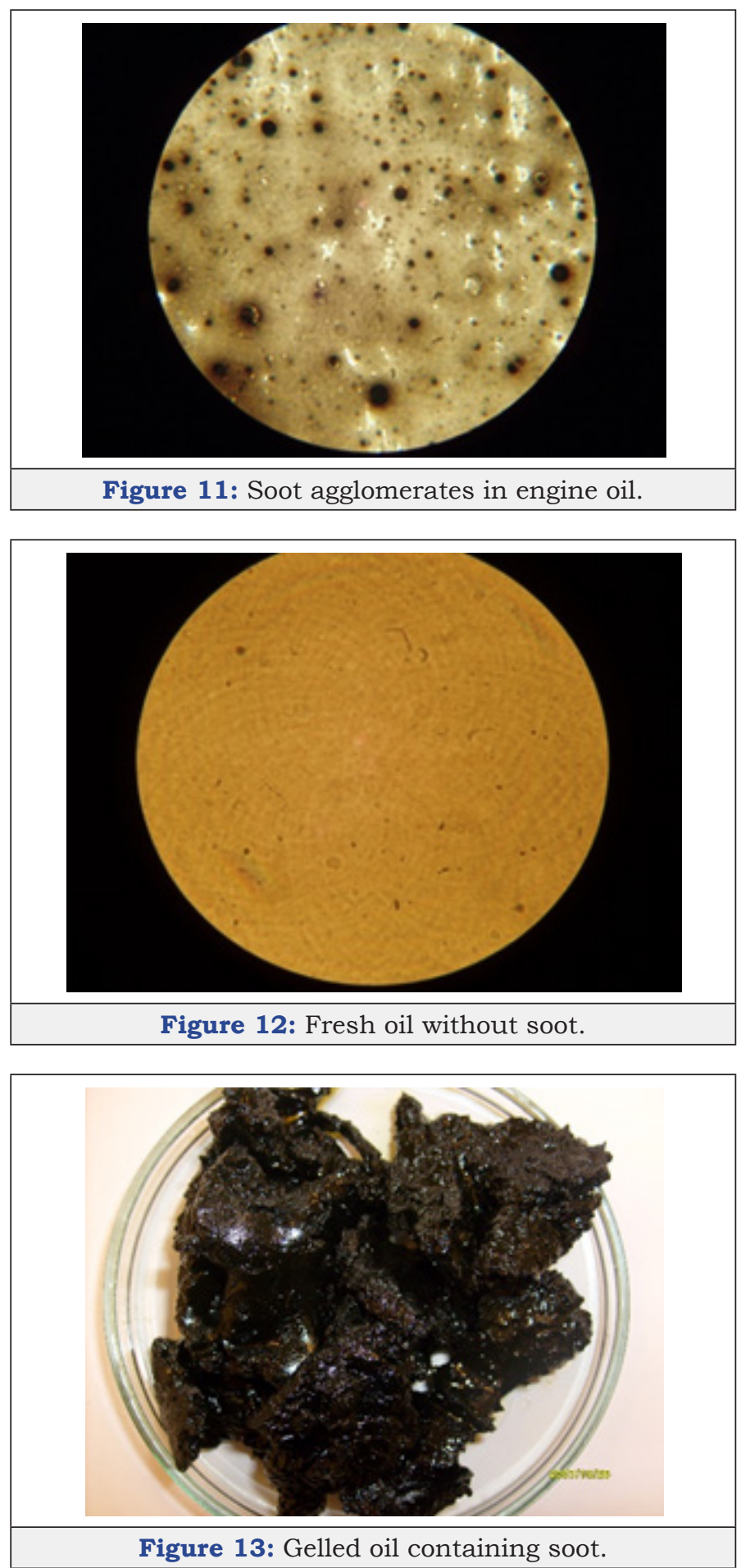


\section{The effect of vegetable oil additive on the process of gelling engine oil}

The process of gelling engine oils can also be caused by the addition of vegetable oil. Under the influence of the high temperature prevailing in the engine polymerization of unsaturated triglyceride bonds and oxidation of vegetable oil occurs, which in consequence may lead to device failure, e.g. by gelling motor oil.

Each vegetable oil, regardless of its origin, easily undergoes aging. How fast this process takes place depends on the amount of unsaturated fatty acids. The fattier acids containing double and triple bonds, the aging process proceeds faster. The factors that accelerate the oxidation process are temperature and oxygen contained in the air. Motor oil containing vegetable oil has a characteristic floral aroma, and its gel is a yellow-brown color. The tests carried out for the content of fatty acids also confirmed the presence of triglycerides of fatty acids - the main components of vegetable oils. Figure 14 shows gelled engine oil containing added vegetable oil [14].

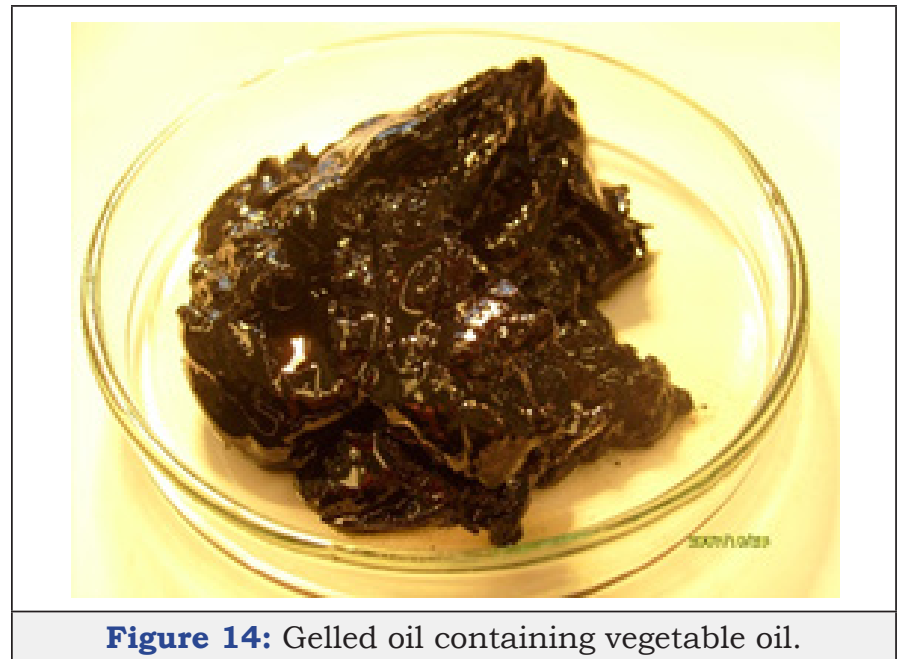

\section{Conclusion}

The literature data show that the temperature has a very large effect on the gelling process of engine oils, which was confirmed in laboratory tests. Based on the conducted tests it can be concluded that the reason for the process of gelling of engine oil:

\section{At low temperatures is:}

A. Paraffin, which cannot be completely removed from the base oil, because paraffin hydrocarbons are a component of crude oil. The gelation process is often associated with the precipitation of paraffins, especially at low temperatures

B. The tendency to retain air and thus the increase in viscosity, which hindered the flow of oil,
C. Too high flow and solidification temperature

D. Addition of a gelling agent, e.g. fatty acid methyl esters or other compounds containing hydroxyl groups of the glycol type

2. At high temperatures it is:

A. Agglomeration of soot in engine oil

B. Addition of vegetable oil

Most problems related to the thickening of engine oil, regardless of temperature, can be avoided by monitoring the degree of engine oil contamination during operation (especially gelling substances, sediments, solid particles, and soot). Routine oil analysis can help detect problems with oil gelling before significant engine damage occurs.

\section{References}

1. Jaworska M, Vogt O (2013) Pochodne sorbitolu i celulozy jako czynniki żelujące. Chemik 67(3): 242-349.

2. Przygocki W, Włochowicz A (2001) Fizyka polimerów. PWN Wydawnictwo Naukowe Poland.

3. Rubinstein M, Colby RH (2003) Polimer Physics, Oxford UK.

4. Kavanagh Gaynor M, Simon B Ross Murphy (1998) Rheological characterization of polymer gels. Prog Polym Sci 23(3): 533-562.

5. Caprotti R (1998) Harm free use of diesel additives. SAE Technical Paper Series 982569.

6. http://zmienolej.pl/pl/blog/kompendium-wiedzy/jak-ocenic-jakoscoleju-silnikowego

7. Selby TW, Müller GC (2008) Thermal history of the engine oil and its effects on low temperature pumpability and gelation formation, paper SAE International.

8. http://www.machinerylubrication.com/Read/30447/combat-oilgelation

9. Beran E (2008) Wpływ budowy chemicznej bazowych olejów smarowychna ich biodegradowalność I wybrane właściwości eksploatacyjne. Prace Naukowe Wydziału Chemicznego Politechniki Wrocławskiej Monografie 5(5): 178.

10. ASTM D 5133-15-Standard test method for low temperature, low shear rate, viscosity/temperature dependence of lubricating oils using a temperature- scanning technique.

11.Ziółkowska M, Biernat K (2018) Skłonność olejów silnikowych do tworzenia żelu w niskich temperaturach. Przemysł Chemiczny 97(6): 938-941.

12. Urzędowska W, Stępień Z (2012) Wybrane zagadnienia dotyczące zmian właściwości silnikowego oleju smarowego w eksploatacji. Nafta-Gaz 68(12): 1102-1110.

13. Jakóbiec J, Budzik G (2007) Czynniki mające wpływ na stopień degradacji oleju silnikowego wokresie eksploatacji. Archiwum Motoryzacji 3: 209216.

14.Ziółkowska M (2009) Proces żelowania olejów silnikowych w czasie eksploatacji pojazdów zasilanych olejem napędowym. Przemysł Chemiczny 88(3): 268-271. 